\title{
DOMAIN MULTIKULTUR DAN PROBLEMATIKA DIDAKTIK GURU DALAM PEMBELAJARAN IPS DI SEKOLAH DASAR BERDASARKAN KURIKULUM 2006
}

\author{
Sudiatmaka, K. Purnawati, Lasmawan \\ Jurusan PKn, Fakultas IImu Sosial \\ Universitas Pendidikan Ganesha Singaraja-Bali
}

\begin{abstract}
Abstrak
Tujuan jangka panjang penelitian ini adalah terwujudnya model pendidikan multikultur sekolah dasar dan perangkat pembelajarannya yang terdiri dari: (1) model pendidikan multikultur SD, dan (2) perangkat pembelajaran yang sesuai dengan karakteristik Kurikulum 2006. Target khusus penelitian ini adalah untuk menghasilkan model pendidikan multikultur yang cocok untuk anak sekolah dasar, dan perangkat pembelajarannya yang memenuhi kriteria valid, praktis, efektif, dan sesuai dengan karakteristik kurikulum 2006. Pencapaian tujuan tersebut akan dilakukan dengan melakukan penelitian pengembangan tipe prototypical studies, dengan prosedur: (1) front-ended analysis (analisis hulu-hilir), (2) prototyping phase (pengembangan prototife), dan (3) assessment phase (fase penilaian). Hasil penelitian menunjukkan bahwa: phenomena didaktik yang dihadapi oleh guru dalam membelajarkan IPS kelas I dan II adalah terkait dengan: keterbatasan sarana dan media pembelajaran, sulitnya mengakses sumber belajar, guru sulit membelajarkan materi dalam bentuk bercerita, dan model pembelajaran guru cenderung bersifat searah dan kurang kondusif. Model pendidikan IPS berbasis multikultur dalam penelitian ini ternyata memacu siswa untuk lebih giat dalam mempelajari hal-hal yang bersifat spiritual, dan setelah dilakukan eksperimentasi terbatas, ternyata model pembelajaran IPS berpendekatan multikultur dapat meningkatkan hasil belajar IPS secara signifikan, baik pada siswa dengan sikap spiritual tinggi maupun rendah.
\end{abstract}

Kata kunci: pendidikan multikultur, pendidikan IPS, modul berbasis masalah

\begin{abstract}
The long-targetted aims of this research is the establishing multicultural education model for primary school and instructional instrument such as (1) primary school multicultural education model, and (2) instructional instruments which are inline with 2006 curriculum. The specific aims of this research are to produce multicultural education model for primary school students and instructional instruments which are valid, practicable, effective and suitable with 2006 curriculum. Those aims will be achieved by conducting a research development with prototypical studies type, in which particular procedures were applied such as (1) front-ended analisis, (2) prototyping phase, and (3) assessment phase. The result of the study showed that didactive phenomenon faced by teachers in social science classes in grade 1 and II was related with the limitation of instructional facilities, the difficulty of acessing knowledge sources, the difficulty of applying instructional model in the form of story-telling, and the tendecy of teachers to have one-direction teaching which is less condusive. The multicultural education model
\end{abstract}


in social science classes in this study enhanced students to work harder in studying spiritual things. Also, after conducting limited-experimentation, it was found that social-science instruction with multicultural approach could improve the students achievement significantly, for either students with high-spiritual attitude or low.

Key words: multicultural education

\section{PENDAHULUAN}

Negara Indonesia adalah sebuah komunitas yang unik dan sangat multi etnis, agama, budaya, dan bahasa (Muqtafa, 2008). Identitas ini merupakan kebanggaan sekaligus ancaman bagi kedirian bangsa Indonesia. Oleh sebab itu, upaya internalisasi paham dan perilaku multikultur merupakan kewajiban setiap insan Indonesia agar keutuhan negara kesatuan republik indonesia (NKRI) tetap bisa dipertahankan. Paradigma multikultural yang marak didengungkan sebagai langkah alternatif dalam rangka mengelola masyarakat multikultur sebagaimana Indonesia tampaknya masih memerlukan perjalanan panjang dan berliku (Muqtafa, 2008). Gagasan genuine ini belum mampu diejawantahkan, baik oleh masyarakat maupun pemerintah, dalam tindakan praksis (Dantes, 2008). Phenomena legal-sosial sperti munculnya keinginan sekelompok orang supaya hukumhukum yang bersumber dari agama yang dipeluknya dilegalisasi masuk ke dalam KUHP tanpa proses objektifikasi, merupakan potret riil belum dipahami dan dihayatinya potensi multikultur oleh sebagian besar masyarakat Indonesia.

Politik sentralisme kekuasaan yang pada masa Orde Baru memaksakan "monokulturalisme" yang nyaris seragam adalah bukti nyata belum dipahaminya multikultural oleh masyarakat, termasuk oleh para pengambil kebijakan hingga saat ini (Dantes, 2009). Selanjutnya dikatakan juga bahwa monokulturalisme ini telah memunculkan reaksi balik, yang mengandung implikasi-implikasi negatif bagi rekonstruksi kebudayaan Indonesia yang multikultural. Berbarengan dengan proses otonomisasi dan desentralisasi kekuasaan pemerintahan, terjadi peningkatan gejala "provinsialisme" yang hampir tumpang tindih dengan "etnisitas" yang mengarah pada "tirani minoritas dan dominasi mayoritas". Politik identitas kelompok, seiring dengan menggejalanya komunalisme, makin menguat, yang pada akhirnya memicu munculnya konflik antar suku maupun agama bak cendawan di musim hujan. Kesatuan dan persatuan yang diidam-idamkan selama ini ternyata semu belaka, sehingga yang mengemuka kemudian adalah kepentingan antar suku, daerah, ras ataupun agama dengan mengesampingkan realitas atau kepentingan yang lain (Muqtafa, 2008 Dantes, 2008). Faktor lain yang turut menyebabkan mandulnya pendidikan multikultural pada tingkat praksis disinyalir disebabkan oleh masih dominannya wacana "toleransi" dalam menyikapi realitas multikultural tersebut.

Pengembangan nilai-nilai budaya lokal dan primordial seperti stereotipe, etnosentrisme dan sebagainya, memang dapat menimbulkan perpecahan yang berbahaya. Tetapi

Jurnal IImu Sosial dan Humaniora|423 
konsep primordialisme itu sendiri memerlukan kajian yang lebih proporsional. Apalagi akibat proses globalisasi, kita sering terasa "sepi" dan memerlukan ikatan komunitas lama yang akrab (Banks, 1996). Itulah sebabnya pada batas tertentu yang relevan, bisa dipahami kemunculan gerakan-gerakan indigenous people yang telah marak terjadi di banyak negara. Gerakan indigenous people ini, seperti gerakan Quebec di Kanada maupun etnis Kurdi di Timur Tengah. Dantes (2009) dalam penelitiannya terhadap siswa SMP di kota Singaraja, menemukan bahwa: (1) pembelajaran IPS dan PKn sebagai mata pelajaran yang paling banyak mengandung "ruang pendidikan multikultur" masih sangat kental dengan indoktrinasi konsepkonsep akademis semata, dan relatif mengabaikan "makna multikultur" dalam struktur materi maupun aplikasi pembelajarannya, dan (2) guru belum memiliki wawasan dan keterampilan yang memadai tentang model pengembangan dan pembelajaran materi multikultur, sehingga domain multikultur cenderung terabaikan dalam format kesengajaan.

Temuan penelitian di atas, mengindikasikan bahwa pendidikan multikultur belum menjadi "perhatian dan fokus" kegiatan instruksional yang dilakukan oleh guru. Implikasinya adalah mungkin saja siswa pintar tentang konsep pancasila, politik, dan hukum, namun belum memiliki pemahaman dan keterampilan hidup yang memadai tentang keberagaman budaya bangsa dan negaranya. Berdasarkan latar belakang masalah di atas, maka dapat diformulasikan rumusan masalah penelitian pada tahun 2 (tahap II) ini sebagai berikut: (1) Bagaimana phenomena didaktik yang dihadapi oleh guru kelas-kelas awal pada sekolah dasar di kota Singaraja Bali ? (2) Bagaiamana candraan kompetensi dan model pembelajaran IPS pada siswa kelas-kelas awal sekolah dasar yang dikembangkan oleh guru saat ini ? (3) Bagaimana rancangan awal (prototife) model pembelajaran multikultur berbasis masalah yang berorientasi spiritualisme yang relevan dikembangkan dalam pembelajaran IPS pada siswa kelaskelas awal sekolah dasar ? (4) Bagaimana rancangan awal (prototife) buku ajar IPS berbasis masalah yang berorientasi spiritualsme yang relevan dikembangkan untuk siswa kelas awal sekolah dasar?

Bagaimana mengatasi problematika negatif dalam keberagaman bangsa Indonesia? Sebagai salah satu media adalah pendidikan yang sangat besar peranannya dalam membentuk karakter bangsa. Salah satu bagian penting pendidikan untuk menanamkan konsep keberagaman adalah IPS. Pembelajaran IPS sangat besar pengaruhnya dalam membentuk kesadaran dan karakter bangsa. Secara substansial, IPS dapat mengembangkan kesadaran multikultural yang bersifat normatif. Apakah implementasi pendidikan yang dilaksanakan selama ini telah mencapai taraf normatif ? atau sekedar pendidikan multikultural deskriptif, yang hanya memberikan penjelasan bagaimana bangsa Indonesia dengan Bhinneka Tungga lka layaknya mutiara di katulistiwa ?. Pertanyaan tersebut harus mendapat jawaban dari berbagai fihak melalui serangkaian upaya terprogram dan bertujuan, sehingga apa yang 
menjadi misi pendidikan nasional benarbenar mampu diterjadikan secara nyata.

Frazier dan Garcia seperti yang dikutip Tilaar (2004:122), menyatakan bahwa yang dimaksud dengan pendidikan multikultur adalah: ".. is a concept frame work, a way of thinking, a philosophycal view point, a value orientation, and a set of criteria for making decission that better genie the educational needs of culturally diverse student populations". Appiah (1994) menyatakan bahwa pendidikan multikultur menekankan pada kesederajatan dalam memperoleh kesempatan pendidikan kepada seluruh masyarakat yang memasukkan seluruh partisipasi siswa dalam berbagai hal, seperti yang ia ungkapkan sebagai berikut: "we may define multicultural education as a field study designed to increase educational equity for all students that incorporates, for this purpose, content, concepts, principles, theories, and paradigms from history, the social and behavioral sciences, and particulary from ethnic studies and women studies".

Sementara Asyari'e, (2004) menyatakan bahwa yang dimaksud dengan pendidikan multikultur adalah proses penanaman cara hidup menghormati, tulus, dan toleran terhadap keanekaragaman budaya yang hidup di tengah-tengah masyarakat plural. Melalui pendidikan multikultur, diharapkan adanya kekenyalan dan kelenturan mental bangsa menghadapi benturan konflik sosial, sehingga kesatuan dan persatuan bangsa tidak mudah patah dan retak. Bank (1995) menyatakan bahwa: "multicultural education nonetheless represents a change in educational thinking, because that is can help individuals and communities value and preserve their own cultural uniqueness, so can serve the same function more generally".

Secara tipologis, menurut Banks (1995) terdapat lima model pendidikan multikultur yang berkembang, yaitu: (1) mengajar kelompok siswa yang memiliki budaya yang lain (cultural difference), (2) hubungan manusia (human relation), membantu siswa dalam melakukan percampuran antar kelompok, (3) single group studies, yakni program yang mengajarkan hal-hal yang memajukan pluralisme tetapi tidak menekankan adanya stratifikasi sosial dalam masyarakat, (4) pendidikan multikultur melalui reformasi pendidikan yang menyediakan kurikulum serta materi pelajaran yang menekankan kepada adanya perbedaan siswa dalam bahasa, yang keseluruhannya untuk memajukan pluralisme kebudayaan dan equalitas sosial, (5) pendidikan multikultural yang sifatnya rekonstruksi sosial, dengan tujuan menyatukan keberagaman dan menantang ketimpangan sosial yang ada dalam masyarakat.

\section{METODE PENELITIAN}

Penelitian ini menggunakan pendekatan penelitian pengembangan alam Plomp dan Akker yang dimodifikasi menurut langkah-langkah penelitian pengembangan Borg dan Gall (Lasmawan, 2010). Penelitian ini dilakukan di Kabupaten Buleleng, dengan menjadikan siswa sekolah dasar kelas I dan II serta guru sebagai sampel penelitian. Jumlah sampel dalam penelitian tahun ke-2 ini adalah 4 kelas siswa kelas I dan II yang jumlah keseluruhannya adalah 260 orang siswa. Instrumen yang digunakan dalam

Jurnal IImu Sosial dan Humaniora |425 
penelitian tahun ke-2 ini terdiri dari: (1) tes hasil belajar IPS, (2) pedoman wawancara, (3) lembar observasi, dan (4) kuisioner tentang kepuasan sampel terhadap model. Keseluruhan data dalam penelitian ini dianalisis dengan menggunakan metode analisis deskriptif kualitatif dan analisis multivariat (Manova).

\section{HASIL PENELITIAN}

Setelah dilakukan análisis data secara menyeluruh dan pemaknaan terhadap setiap domain akademis yang dilibatkan dalam penelitian, maka dapat disajikan hasil penelitian sebagai berikut.

Phenomena didaktik yang
dihadapi oleh
membelajarkan IPS pada siswa kelaskelas awal sekolah dasar, secara umum adalah terkait dengan: (1) keterbatasan saran dan media pembelajaran, (2) sulitnya mengakses sumber belajar, (3) guru sulit membelajarkan materi dalam bentuk bercerita, (4) model pembelajaran guru cenderung bersifat searah dan kurang kondusif, dan (5) dalam pengelolaan pembelajarannya, guru cenderung langsung mengambil alih pembelajaran pada saat jawaban atau tanggapan yang disampaikan oleh siswa kurang tepat, dengan tanpa memberikan kesempatan kepada siswa untuk memperbaiki jawabannya.

Candraan materi dan kompetensi mata pelajaran IPS di kelaskelas awal sekolah dasar secara umum berisikan kompetensi yang terkait dengan: lingkungan, kesenangan diri (hobi), kebersihan, kerjasama, dan tempat-tempat umum (public area), yang tersaji secara berurutan sesuai dengan semester dan kelasnya.
Sementara model pembelajaran yang saat ini banyak dikembangkan oleh guru adalah model ceramah dan penugasan rumah (PR), yang bagi siswa sangat membosankan dan kurang menarik minat belajar mereka. Siswa menempatkan pelajaran IPS sebagai mata pelajaran yang membosankan dan kurang menarik untuk dipelajari, karena materinya terlalu sulit dan bersifat hapalan, dan guru dalam menyampaikan materinya seperti "penjual obat" di pasar-pasar, yaitu hanya ceramah dan menyampaikan cerita itu-itu saja.

Pengembangan model pembelajaran multikultur dan buku ajar IPS berbasis multikultur yang berorientasi spiritualisme dilakukan dengan mekanisme sebagai berikut: (1) fokus group discussion, (2) individual perspektif, (3) seminar dan lokakarya, (4) simulasi model, dan (5) justifikasi dan validasi model. Adapun struktur materi pendidikan multikultur yang dikembangkan dalam pembelajaran IPS dan PKn disesuaikan dengan karakteristik dari masing-masing mata pelajaran dan candraan Standar isi (SI), standar kompetensi (SK), dan kompetensi dasar (KD) dari masingmasing mata pelajaran pada setiap semesternya. Di sisi lain, sebelum menerapkan model pembelajaran dan aplikasi materi multikultur, kepada guru direkomendasikan beberapa prinsip dasar, yaitu: kaji secara matang karakteristik materi ajar sebelum merancang dan memasukkan materi pendidikan multikultur kedalam satuan mata pelajaran IPS dan/atau PKn, (2) identifikasi kemultikulturan siswa dan lingkungan masyarakatnya, (3) refleksi kemampuan dan keterampilan diri, serta 
akses informasi kemultikultural yang tersedia, dan (4) penyajian pembelajaran yang berpusat kepada siswa, sehingga dominasi pembelajaran tidak lagi ada di tangan guru. Buku petunjuk guru yang akan dikembangkan dalam penelitian tahun ke-2 akan ditata sedemikian rupa, dimana bagian kiri merupakan bagian yang ada pada buku siswa (sama dengan apa yang terdapat pada buku siswa), sedangkan di sebelah kanannya berupa petunjuk dan komentar apa yang semestinya dilakukan oleh guru dan siswa. Hal ini hanya sebagai stimulan saja, dimana guru bebas mengembangkan atau memodifikasi sesuai dengan kebutuhan dan situasi pembelajaran yang dihadapinya.

$\begin{array}{ccc}\text { Bentuk akhir dari model } & \text { malikultur } \\ \text { pendidikan } & \text { multikum }\end{array}$
pembelajaran IPS menganut paradigma sekuensi-karakteristik materi, yaitu sebaran materi multikultur disesuaikan dengan karakteristik materi yang muncul di setiap semester dan kelas pada masing-masing mata pelajaran, sehingga tidak mengabaikan struktur kurikulum yang telah ditetapkan. Sementara pokok-pokok materi pendidikan multikultur yang visibel dikembangkan dalam pembelajaran IPS secara integralistik dan holistik adalah: Ideologi Pancasila/UUD 1945, Bahasa Indonesia, Bendera Kebangsaan, Lagu Kebangsaan, Bhineka Tunggal Ika, Peraturan Perundang-undangan, Tat Twam Asi (Persaudaraan Universal), Ahimsa (Anti Kekerasan), Karma Phala (Hukum Karma), Tri Hita Karana (Ekosentrisme/ Kosmosentrisme), Rwa Bhineda (Dualisme Kultural/Oposisi Biner), Desa, Kala, Patra (Pluralisme), Menyama Braya (Solidaritas
Sosial/Modal Sosial), Tri Samaya (Kesadaran Sejarah), Skriptualisme, Intuisionisme, Rasionalisme, Empirisme, Keragaman, Kebersamaan, Kesetaraan, Kesejahteraan, Kemanusiaan, Proporsional, Keadilan, Anti hegemoni dan Demokratis, Dominasi, Toleransi, Keterbukaan, Dialogis, Adaptif, Kejujuran, Empati, Tanggung jawab, Altruisme, dan Kerjasama. Sementara model penilaian yang dikembangkan untuk pendidikan multikultur adalah penilaian proses, penilaian hasil, dan penilaian kinerja. Bentuk dari instrumen penilaian pendidikan multikultur yang visibel untuk dikembangkan antara lain: (1) self-esteem, (2) penilaian kinerja, (3) skala sikap, (4) tes keterampilan sosial, (5) penilaian literasi sosial-budaya, (6) skala sikap, (7) tes keterampilan berpikir, (8) penilaian proyek, dan (9) penilaian patnershif (penilaian antar siswa). Bentuk akhir dari model pembelajaran berbasis multikultur terdiri dari komponen-komponen yang sinergis mutualis dengan tahapan: (1) inisiasi, (2) eksplorasi, (3) eksplanasi, (4) peer group analisis, (5) expert-opinion, dan (6) refleksi-perumusan komitmen.

Hasil uji hipotesis kedua dan ketiga mengindikasikan adanya pengaruh interaksi antara pendekatan multikultur dan sikap spiritualisme terhadap prestasi belajar IPS siswa. Indikasi ini dipertegas oleh hasil uji ANAVA $2 \times 2$ yang menghasilkan nilai Fhitung sebesar 91.47 yang lebih besar dibandingkan dengan nilai Ftabel sebesar 8.26 untuk taraf signifikansi 0.05. Hasil ini menunjukkan bahwa Ho ditolak dan $\mathrm{H} 1$ diterima, sehingga terdapat pengaruh interaksi yang signifikan antara pendekatan multikultur

Jurnal IImu Sosial dan Humaniora |427 
dan sikap spiritualisme terhadap prestasi belajar IPS.

\section{PEMBAHASAN}

Berdasarkan hasil penelitian di atas, maka dapat dilihat secara umum, guru yang dilibatkan dalam penelitian ini sebagai guru mitra rata-rata kualifikasi pendidikannya adalah Strata 1 (S1), sehingga telah memenuhi persyaratan minimal sebagaimana yang diharuskan oleh PP Nomor 19 Tahun 2005 tentang Standar Nasional Pendidikan, khususnya yang mengatur tentang standar pendidikan tenaga pendidik (guru) sekolah dasar. Sementara dilihat dari karakteristik kelaminnya, sebagian besar adalah guru perempuan. Di sisi lain, dilihat dari pengalaman mereka mengikuti pelatihan atau pertemuan ilmiah yang terkait dengan pengembangan profesinya, rata-rata telah mengikutinya lebih dari $10 \mathrm{kali}$. Hal ini tentu sangat membantu dalam kaitannya dengan pelaksanaan tugas dan kewajibannya sebagai tenaga profesional dalam bidang ke-IPS-an. Pengalaman ini sebenarnya sangat membantu guru dalam merancang dan melaksanakan pembelajaran yang inovatif. Akan tetapi dilihat dari pengelolaan pembelaran di kelas, guru cenderung menerapkan pembelajaran individual. Sumber pembelajaran yang digunakan adalah buku siswa. Guru mengajar mengikuti materi yang ada pada buku siswa, serta langsung merespon siswa tanpa memberi kesempatan siswa lainnya untuk memberi komentar. Phenomena didaktik yang dapat digunakan sebagai sumber pembelajaran untuk siswa kelas-kelas awal adalah permainan, lingkungan , kebun, diri sendiri, dan keluarga, ke pasar, pengukuran benda, makanan, lingkungan, kegiatan sehari-hari, permainan, kegemaran, dan bagianbagian badan. Semua fenomena didaktik ini sesuai dengan semua anak untuk semua lokasi. Oleh karena itu, sebagai fenomena didaktik yang digunakan sebagai tema adalah keluarga, kebun, pasar, sekolah, dan kegiatan sehari-hari.

Dilihat dari usia guru yang mengajar di kelas-kelas awal, dominan mempunyai umur lebih dari 40 tahun, serta berjenis kelamin perempuan. Kiranya pertimbangan guru senior dan sosok perempuan dijadikan sebagai pertimbangan untuk guru kelas-kelas awal. Hal ini dapat dipahami karena siswa pada kelas I, II, dan III yang umurnya sangat muda memerlukan sosok guru yang sabar dan dapat "melindungi", serta "mendidik". Kondisi ini tentu sangat menguntungkan bagi pelaksanaan penelitian ini, khususnya pada saat pengembangan model yang merupakan fokus dari penelitian pada tahun ke-2 (tahap II). Kedewasaan umur dan kematangan akademik guru ini, sangat berkontribusi pada saat dilakukannya perancangan model perangkat pembelajaran yang akan dilakukan pada tahun kedua.

Bertalian dengan hambatan atau kendala yang dihadapi oleh guru dalam membelajarkan materi IPS saat ini, kebanyakan guru menyatakan bahwa mereka kesulitan dalam menyampaikan materi dalam bentuk cerita atau menggunakan pendekatan tematik. Hal ini disebabkan karena mereka belum memiliki atau dilatihkan keterampilan tersebut sebelum diberlakukan-nya kurikulum 2006 yang menunjuk penggunaan pendekatan tematik bagi 
siswa kelas-kelas awal di sekolah dasar. Pada sisi lain, keterbatasan media pembelajaran dan sumber belajar merupakan kesulitan lain yang sangat dirasakan oleh guru dalam membelajarkan IPS saat ini. Bertalian dengan hal itu, pengembangan perangkat pembelajaran berorientasi keterampilan proses dan komunikasi sosial yang menjadi fokus dalam penelitian ini sangat dibutuhkan untuk mengatasi kondisi ini.

Sementara dilihat dari kemampuan pengelolaan pembelajaran yang selama ini dilakukan oleh guru, dapat diformulasikan beberapa hal yaitu: (1) guru masih sering memerankan dirinya sebagai dominator selama berlangsungnya pembelajaran, sumber belajar yang digunakan oleh guru masih terbatas pada penggunaan buku teks atau buku penunjang lainnya yang belum tentu sesuai dengan kebutuhan belajar siswa, (3) media pembelajaran yang digunakan oleh guru masih sangat sederhana, (4) guru sangat jarang memberikan tugas-tugas kelompok kepada siswa, (5) pada saat membelajarkan materi guru cenderung mendominasi kelas, sehingga siswa sangat sedikit punya peluang untuk berpartisipasi selama berlangsungnya pembelajaran, (6) model evaluasi yang dikembangkan oleh guru lebih sering berupa evaluasi produk dengan menggunakan test hasil belajar yang telah ada di bagian belakang buku teks atau buku pegangan siswa. Kondisi ini tentu masih jauh dari harapan pembelajaran IPS yang sebenarnya, sebagaimana yang dikatakan oleh Lasmawan (2006), bahwa pembelajaran IPS harus mampu memfasilitasi berkembangnya keterampilan berpikir dan pelatihan keterampilan sosial kepada siswa selama berlangsungnya pembelajaran, sehingga pembelajaran yang diikutinya benar-benar dirasakan manfaatnya. Kondisi ini juga menjadi harapan dari NCSS (2005), dimana pembelajaran social studies semestinya penuh dengan pelatihan berpikir dan keterampilan sosial, sehingga siswa memiliki kesiapan untuk terjun bermasyarakat dan menjalaninya secara wajar dan bertanggungjawab.

Berdasarkan preposisi di atas, tampaknya pengembangan perangkat pembelajaran yang berorientasi pada keterampilan proses dan komunikasi sosial dalam penelitian ini memiliki nilai strategis dan potensial untuk dikembangkan, sebagai salah satu upaya untuk mengeliminir berbagai persoalan yang melekat pada pembelajaran IPS, sehingga pembelajaran IPS dapat dikembalikan pada fitrahnnya sebagai media pelatihan warga negara yang berkualitas dan bertanggungjawab terhadap permasalahan bangsa dan negaranya dengan tetap dilandasi oleh nilai-nilai nasionalisme Pancasila. Secara konseptual, misi dan substansi pembelajaran pengetahuan sosial di sekolah dasar adalah media strategis dan efektif dalam kaitannya dengan pembangunan warga negara yang berkualitas dan demokratis (Hasan, 2005). Untuk menjadikan pembelajaran pengetahuan sosial yang menarik dan mampu memfasilitasi pengembangan potensi peserta didik secara optimal, maka guru harus mampu mengembangkan ketrampilan proses selama berlangsungnya pembelajaran (NCSS, 2000).

Jurnal IImu Sosial dan Humaniora |429 
Berangkat dari beberapa temuan penelitian di atas, maka pengembangan model pendidikan multikultur berbasis spiritualisme dalam pembelajaran IPS sekolah dasar, baik yang berupa buku pegangan siswa, media pembelajaran, dan buku petunjuk guru akan dilakukan sesuai dengan kondisi riil yang saat ini ada dilapangan, sehingga kedepannya lebih mudah untuk melakukan revisi atau evaluasinya. Hal ini penting, mengingat substansi dari pembelajaran IPS adalah bagaimana melalui interaksi transaksional yang kreatif, siswa dibekali seperangkat kemampuan, pengetahuan, sikap, nilai, dan keterampilan sosial untuk hidup bermasyarakat. Sejalan dengan konsep ini, Schement (2002) menyatakan bahwa substansi dari pembelajaran IPS pada jenjang pendidikan dasar adalah bagaimana siswa mengenal diri dan lingkungannya, sehingga pada saat mereka telah terjun dalam realitas sosial kemasyarakatan dapat mewujudkan civic community.

Civic community menjadi target akhir dari pembelajaran IPS, namun pencapaian kearah itu memerlukan berbagai upaya dari guru, siswa, dan lingkungan sekitar secara holistik dalam format desain instruksional yang berbasis nilai-nilai lokal yang beragam. Salah satu komponen dasar dari pembelajaran IPS menuju terwujudnya civic community adalah pendidikan multikultur (NCSS, 2004). Sehingga pendidikan multikultur merupakan komponen penting dalam substansi kedua mata pelajaran tersebut secara integratif. Preposisi ini sejalan dengan tujuan dari kedua mata pelajaran tersebut dalam hubungannya dengan pembentukan warga negara, yaitu: untuk menjadikan siswa yang paham dan sadar terhadap hak dan kewajibannya sebagai warga negara, maka pembekalan pengetahuan, sikap, dan keterampilan bertoleransi, berdemokrasi, dan berempati harus dilakukan sejak dini.

Di sisi lain, untuk menjadikan siswa memiliki pemahaman yang memadai tentang diri dan masyarakanya, maka pengetahuan dan keberterimaan terhadap berbagai perbedaan yang ada dan berkembang di masyarakat merupakan sebuah keharusan, sebagaimana konsep dasar dari pendidikan multikultur yang dikembangkan dalam penelitian ini. Hilda Hernandez dalam Multicultural Education: A Teacher Guide to Linking Context, Process, and Content (1989), mengartikan pendidikan multikultural sebagai perspektif yang mengakui realitas politik, sosial, ekonomi yang dialami oleh masing-masing individu dalam pertemuan manusia yang kompleks dan beragam secara kultur, dan merefleksikan pentingnya budaya, ras, seksualitas dan gender, etnisitas, agama, status sosial, ekonomi, dan pengecualian-pengecualian dalam proses pendidikan. Atau dengan kata lain, bahwa ruang pendidikan sebagi media transformasi ilmu pengetahuan (transfer of knowledge) hendaknya mampu memberikan nilai-nilai multikulturalisme dengan cara saling menghargai dan menghormati atas realitas yang beragam (plural), baik latar belakang maupun basis sosio budaya yang melingkupinya. Preposisi di atas, sejalan dengan pemikiran Paulo Freire dalam pedagogy of the oppressed, sebagaimana dikutip oleh $M$. Yunus Firdaus dalam buku: Pendidikan 
Berbasis Realitas Sosial (2005), dimana Freire mengatakan bahwa pendidikan harus mampu menciptakan harmonisme sosial dalam sebuah kehidupan masyarakat yang beragam secara kultur. Sebab pendidikan bukanlah "menara gading" yang harus menjauhi hiruk-pikuk kehidupan sosial. Apalagi di negara Indonesia yang rentan terjadi konflik. Karena itu, pendidikan berbasis multikulturalisme sudah saatnya dijadikan sebagai paradigma atau pijakan dalam sistem pendidikan kita. Apapun alasannya, pendidikan multikultural dapat memberikan solusi bagi sejumlah permasalahan yang dihadapi Indonesia.

Pertama, sebagai sarana
alternatif

\section{Penyelenggaraan}

pendidikan multikultural di dunia pendidikan diyakini dapat menjadi solusi nyata bagi konflik dan disharmonisasi yang terjadi di masyarakat, khususnya yang kerap terjadi di Indonesia yang secara realitas plural. Spektrum kultur masyarakat Indonesia yang amat beragam menjadi tantangan bagi dunia pendidikan guna mengolah perbedaan tersebut menjadi suatu aset, bukan sumber perpecahan.

Kedua, pendidikan multikultural juga signifikan dalam membina peserta didik supaya tidak tercerabut dari akar budaya yang ia miliki sebelumnya, ketika berhadapan dengan realitas sosial-budaya di era globalisasi. Sebab disadari maupun tidak, dalam era globalisasi saat ini, pertemuan antarbudaya menjadi "ancaman" serius bagi peserta didik. Untuk menyikapi realitas global tersebut, peserta didik hendaknya diberi penyadaran akan pengetahuan yang beragam, sehingga mereka memiliki kompetensi yang luas akan pengetahuan global, termasuk aspek kebudayaan.

Ketiga, sebagai landasan pengembangan kurikulum nasional. Pengembangan kurikulum masa depan yang berdasarkan pendekatan multikulturalisme menjadi sangat penting. Langkah demikian dapat dilakukan setidaknya dengan mengubah filosofi kurikulum dari yang berlaku seragam seperti saat ini menjadi filosofi yang lebih sesuai dengan tujuan, misi, dan fungsi setiap jenjang pendidikan dan unit pendidikan. Filosofi konservatif seperti esensialisme dan perenialisme haruslah dapat diubah ke filosofi yang lebih menekankan pendidikan sebagai upaya mengembangkan kemanusiaan peserta didik. Kemudian, filosofi kurikulum yang progresif seperti humanisme, progresifisme dan rekonstruksi sosial dapat dijadikan sebagai landasan kurikulum.

Berdasarkan konsepsi dan analisis di atas, pendidikan berbasis multikulturalisme pada akhirnya akan memberikan sebuah pencerahan: yakni kearifan untuk melihat keanekaragaman budaya sebagai realitas fundamental dalam kehidupan masyarakat. Kearifan itu muncul seiring dengan adanya keterbukaan untuk menjalani kehidupan bersama dengan melihat realitas plural sebagai kemestian hidup yang kodrati, sebagaimana dikatakan oleh Asy'ari (2004), bahwa keanekaragaman dalam realitas kehidupan manusia adalah suatu keniscayaan yang tidak bisa dipungkiri. Berangkat dari hasil pengembangan model dan melihat implikasi dari model pendidikan multikultur terhadap capaian belajar siswa, maka dapat diformulasikan preposisi bahwa: pendidikan 
multikultural adalah proses penyadaran yang berwawasan pluralis secara agama sekaligus berwawasan multikultural. Pendidikan multikultur harus dilihat sebagai bagian usaha komprehensif mencegah dan menanggulangi konflik etnis dan agama, radikalisme agama, separatisme, dan disintegrasi bangsa. Hal ini sejalan dengan pendapatnya (Savater, 2006) yang menyatakan bahwa disebabkan karena toleransi merupakan sikap kewargaan yang aktif, bukan sikap yang spontan (La tolerance est une position civique active, et non pas une attitude spontanee), maka sikap toleran tidak akan tertanam dengan sendirinya, tanpa ada usaha sadar menginternalisasikannya. Toleransi harus dididikkan, tidak cukup berhenti pada wacana. Keputusan majelis ulama, keputusan konsili, kesepakatan sidang dewan gereja-gereja sedunia, dan kesepakatan hasil pertemuan tokoh agama yang menganjurkan toleransi tidak akan cukup efektif bila hanya berhenti di kertas dan bibir, tanpa dukungan pendidikan dalam arti luas. Sayang, urgensi pendidikan multikultur belum dirasakan dunia pendidikan dan masyarakat luas, termasuk dalam konteks pembelajaran IPS sekolah dasar.

\section{PENUTUP}

Berdasarkan hasil penelitian dan pembahasan di atas, maka dapat dirumuskan kesimpulan sebagai berikut: (1) phenomena didaktik yang dihadapi oleh guru dalam membelajarkan pengetahuan sosial pada siswa kelas I dan II adalah terkait dengan: keterbatasan saran dan media pembelajaran, sulitnya mengakses sumber belajar, dan model pembelajaran guru cenderung bersifat searah dan kurang kondusif, (2) candraan materi mata pelajaran pengetahuan sosial di kelas I dan II sekolah dasar secara umum berisikan kompetensi yang terkait dengan: lingkungan, kesenangan diri (hobi), kebersihan, kerjasama, dan tempattempat umum (public area), yang tersaji secara berurutan sesuai dengan semester dan kelasnya. Sementara model pembelajaran yang saat ini banyak dikembangkan oleh guru adalah model ceramah dan penugasan rumah (PR), yang bagi siswa sangat membosankan dan kurang menarik minat belajar mereka. (3) Rancangan buku pegangan siswa sebagai salah satu perangkat pembelajaran yang akan dikembangkan dalam penelitian ini berorientasi pada keterampilan proses dan komunikasi sosial, sebagai alternatif untuk mengeliminir berbagai kesulitan yang dialami oleh guru dalam pembelajaran pengetahuan sosial. Buku pegangan siswa ini akan dikemas dalam bentuk sajian materi yang singkat, sederhana, dan praktis, dengan dilengkapi gambar, photo, flochart, maupun peta, sehingga menarik bagi siswa untuk mempelajarinya. (4) Buku petunjuk guru yang akan dikembangkan dalam penelitian tahun ke-2 akan ditata sedemikian rupa, dimana bagian kiri merupakan bagian yang ada pada buku siswa (sama dengan apa yang terdapat pada buku siswa), sedangkan di sebelah kanannya berupa petunjuk dan komentar apa yang semestinya dilakukan oleh guru dan siswa. Dan (5) terdapat pengaruh interaksi yang signifikan antara pendekatan multikultur

Jurnal IImu Sosial dan Humaniora | 432 
dan sikap spiritualisme terhadap

\section{DAFTAR PUSTAKA}

Akker, J.V. (1999). Principles and Methods of Development Research. In J. vam den Akker,R Branch,K Gustafson, N Nieveen and Tj.Plomp (Eds). Design Approaches and Tools in Education and Training (hlm. 114). Dodrecht : Kluwer Academic Publisher.

Appiah, K. A. (1994). Identity, Authenticity, Survival: Multicultural Societies and Social Reproduction. Dalam Amy Gutmann (Ed), Multiculturalism. Princeton, Ney Jersey: Princeton University Press.

Asyar'i, L. (2004). Membebaskan Diri dari Keterikatan Lokal. Kompas, Tanggal 3 September 2004.

Banks, J. and Banks. (1995). Teaching strategies for ethnic studies. Boston: Allyn and Bacon.

Banks, J. (1995). Multicultural Education. available at. www.multiculturalism.com. Akses 21/08/2006

Beyer, B. K. (1979). Teaching Thinking in Social Studies: Using Inquiry in the Classroom. Columbus: Charles E. Meril Publishing Company \& A Bell \& Howell Company.

Bunyamin, S. (2004). Kesiapan guru PPKn mengembangkan pendidikan nilai-nilai kejuangan. (Disertasi). Bandung: PPS UPI prestasi belajar IPS.

Boyer, E. L. (2000). Civic education for responsible citizen. Educational Leadership, 48-Nov, 4-9.

Dantes, N. (2007). Mulyikulturalisme dalam pembelajaran PKn SD (Laporan Penelitian). Singaraja: Lembaga Penelitian Undiksha.

Dodd, C. H. (1998). Dynamics of Intercultural Communication (Fifth Edition). New York: McGraw-Hill.

Educational for Democracy Project. (2002). Education for democracy. American Federation of Teachers, 313 (5), 57-62.

Fadjar, A. M. (2004). Holistika Pemikiran Pendidikan. Jakarta: Radja Grafindo Persada.

Gorski, P. (2003). Six Critical Paradigm Shiifd For Multicultural Education and The Question We Should Be Asking, dalam www. Edchange.org/multicultural.

Hasan, S.H. (2005). Pembaharuan Pendidikan IPS di Era Otonomi Pendidikan. (Makalah). Disajikan dalam seminar sehari Fakultas PIPS IKIP Negeri Singaraja. Singaraja: FPIPS IKIP Negeri Singaraja.

Heller, C. \& Hawkins, J. (1994). Teaching tolerance: Notes from the front line. Teachers College Record, Number 95. page 337368.

Hidayat, Eddy M. (1997). Pendidikan Sains untuk Kelompok Multi Etnis. Mimbar Pendidikan (1) Tahun XVI 1997.

Jurnal IImu Sosial dan Humaniora|433 
IKA UIN Syarif Hidayatullah. (2003). Mengagas Pendidikan Multikultural. Majalah Tsaqafah, Vol. I No: 2, 2003.

Inten, G. (2005) Pengembangan model resolusi konflik dalam pembelajaran IPS pada sekolah dasar negeri di Kecamatan Tejakula - Buleleng. (Thesis). Singaraja: Program Pascasarjana IKIP Negeri Singaraja

Jandt, F.E. (1998). Intercultural Communication, An Introduction (Second Edition). Thousand Oaks, California: SAGE Publication, Inc.

Jannes, E. W. (2001). Konflik Antar Etnis, Ujian Bagi Budaya Lokal. Kompas, 21 Maret 2001.

Katryn, R. (2000). Ketegangan Anta Etnis, Orang Bugis dan Masalah "Penjelasan". Jurnal Antropologi Indonesia, Nomor 63 Tahun XXXIV, September - Desember, 2000.

Kertih, W. (2005). Analisis Kurikulum IPS dan PPKn Sekolah Dasar. (Laporan Penelitian). Singaraja: Singaraja: Lembaga Penelitian IKIP Negeri Singaraja

Kurikulum IPS - SD 2006. (2006). Jakarta: Departemen Pendidikan Nasional, Dirjen Pendidikan Dasar dan Menengah.

Lasmawan, W. (2006). Pengembangan buku ajar berwawasan sosialbudaya dalam pembelajaran mata kuliah pengantar ilmu sosial dan pendidikan ilmu sosial pada mahasiswa Jurusan PPKn FIS Undiksha (laporan penelitian). Singaraja:

Maria, H. (2001). Asimilasionisme vs Multikulturalisme. Kompas, 14 Maret 2001.

McCarthy, C. (1994). Multicultural discourses and curriculum reform: A critical perspective. Educational Theory, number 44-vol.1, page 8183.

Miller, S. A. (1998). Developmental Research Methods. Second Edition. New Jersey: Prentice Hall.

Montgomery. (1994). Design and Anaysis of Experiments. New York : Wiley \& Son

Moultry, M. (1988). Multicultural education among seniors in the College of Education at Ohio State University. Educational Research, 45 (2). 124-126.

NCSS. (2004). Science-TechnologySociety (STS) in Social Studies: Position Paper. Washington DC: NCSS.

NCSS. (2005). Guidelines for Teaching About Science/Technology/Society in Social Studies: Education for Citizenship in the 21st Century. (On line). Available at http://www.uow.edu.au/sts/ncss/ pubs/00nvt.html. 